\title{
Heat Protective Coatings on Niobium Alloys
}

\author{
V. P. Babak ${ }^{1}$ • B. A. Lyashenko² $\bullet$ V. V. Shchepetov ${ }^{1} \bullet$ S. D. Kharchenko ${ }^{1}$
}

Received: 27 September 2020 / Accepted: 24 November 2020

\begin{abstract}
The article shows that during plasma-diffusion deposition, a multilayer coating was formed on the surface of the niobium alloy. A highly porous plasma-sprayed layer of molybdenum silicide has a significant spread in thickness $(h=100 \ldots 350 \mu \mathrm{m}, \mathrm{H} \mu 20=6880 \mathrm{MPa})$. When studying the microstructure of samples with a plasma-diffusion coating after testing, it was found that cracks in the coating originate in the process of creep, mostly at the interface between the plasma and diffusion layers of the coating. The source of their origin is individual discontinuities in the diffusion layer as delivered. Crack propagation occurs both into the plasma and diffusion layers of the coating. Crack growth in the plasma layer is inhibited due to the rounded nature of the pores and the increased plasticity of this layer. The growth of cracks deep into the sample is, as a rule, inhibited by a boride sublayer. The advantage of plasma-diffusion technology provided an increased plasticity of the coating, the presence of thin barrier sublayers, a discontinuous coating structure, the presence of low-melting compounds that contribute to the healing of defects in the coating, an increase in its corrosion resistance and resistance to thermal fatigue destruction. The combination of these properties made it possible to provide an increase in durability compared to silicide and borosilicide coatings under conditions of isothermal creep in air $\left(1400{ }^{\circ} \mathrm{C}, 50 \mathrm{MPa}\right) 1.9 \ldots 3.7$ times and under conditions of thermal cyclic creep $\left(1400-250{ }^{\circ} \mathrm{C}, 50 \mathrm{MPa}\right)$ in $6.8 \ldots .8 .5$ times. It has been determined that the use of a discrete structure will increase the thickness of the coating layer and ensure an increase in their working properties.
\end{abstract}

Keywords: alloy, multicomponent coatings, plasma-diffusion coatings, heat strength, heat resistance.

\section{Introduction}

Nickel alloys, which provide heat resistance of hightemperature paths of many generations of aerospace technology, have practically realized their technical potential. Improving their performance due to traditional strengthening technologies have almost completely exhausted themselves, in particular, doping, as an effective method of interaction on the structure and properties, has practically used its potential. The operating temperature of nickel alloys is $\sim 1100{ }^{\circ} \mathrm{C}$ and is $80-85 \%$ of the melting point of the nickel matrix (solid solution based on Nickel) $\sim 1350{ }^{\circ} \mathrm{C}$. Niobium and its alloys are one of the real competitors of nickel materials, the areas of application of which are in-

V.P. Babak vdoe@ukr.net

${ }^{1}$ Institute of Engineering Thermophysics of the National Academy of Sciences of Ukraine, Kyiv, Ukraine

${ }^{2}$ G.S. Pisarenko Institute for Problems of Strength of the National Academy of Sciences of Ukraine, Kyiv, Ukraine tensively studied. High heat resistance and moderate density, approximately equal to the density of alloy steels, allow us to consider niobium alloys as a replacement for nickel superalloys in aerospace gas turbine construction. Also promising niobium alloys in ground and space nuclear power plants. Table 1 shows a comparative analysis of the physical and mechanical characteristics of nickel and niobium as the basis materials of heat-resistant alloys.

Table 1. Physico-mechanical characteristics of nickel and niobium

\begin{tabular}{|c|c|c|c|c|c|}
\hline & $\begin{array}{c}\text { Jung's } \\
\text { module, } \\
\mathrm{GPa}\end{array}$ & $\begin{array}{c}\text { Den- } \\
\text { sity, } \\
\mathrm{g} / \mathrm{cm}^{3}\end{array}$ & $\begin{array}{c}\text { Brinell } \\
\text { hardness, } \\
\mathrm{MPa}\end{array}$ & $\begin{array}{c}\text { Coefficient of } \\
\text { thermal linear } \\
\text { expansion, } \\
10^{-6} \cdot \mathrm{K}^{-1}\end{array}$ & $\begin{array}{c}\text { Melting } \\
\text { point, } \\
{ }^{\circ} \mathrm{C}\end{array}$ \\
\hline $\mathrm{Ni}$ & 200 & 8,91 & 700 & 13,5 & 1455 \\
$\mathrm{Nb}$ & 155 & 8,57 & 750 & 7,08 & 2469 \\
\hline
\end{tabular}

However, the main obstacle to the introduction of niobium alloys is the problem of their interaction with active gases and high-purity coolants. 
Thus, the rate of oxidation of niobium in air at a temperature of $1100{ }^{\circ} \mathrm{C}$ is $300 \ldots 350 \mathrm{~g} / \mathrm{g} \cdot \mathrm{m}^{2}$ [1]. They try to solve the protection problem by using special heat-resistant alloys with higher resistance to corrosion damage. Thus, doping of niobium with various additives reduces the rate of its oxidation in air at $1100{ }^{\circ} \mathrm{C}$ to $40 \ldots 1250 \mathrm{~g} / \mathrm{g} \cdot \mathrm{m}^{2}$ (however, this level of oxidation intensity is much higher than the allowable limits) [1]. Therefore, the main direction is the use of protective multifunctional coatings.

The aim of the work is to outline the tendencies and means of optimal increase of their durability on niobium alloys in oxidizing environment, as well as to determine the conditions of reduction of initial strength and deformability of niobium alloy during coating.

\section{Problem status}

Many studies, including reviews [2-5], are devoted to the development of coatings on niobium alloys. The basic physicochemical principles of creating heat-resistant heterophase coatings and groups of coatings for different temperature-time intervals are considered [6].

Almost all surface hardening technologies have been tested to strengthen niobium alloys. Ni-coating was applied by traditional galvanic technology [2]. The prospects of silicate deposition at asymmetrically rectified current are shown. Up to $900{ }^{\circ} \mathrm{C}$, composite electrolytic coatings of the Ni-B-Cr system work successfully in air. However, the use of galvanic coatings is prevented by the solubility of hydrogen in niobium, which dramatically reduces its ductility [1].

The most widespread methods of chemical and thermal treatment of niobium alloys. Traditional alliteration, silicification, drilling are used [2-7]. Analyzing the advantages and disadvantages of aluminide and silicide coatings, note the prospects of coatings based on complex silicides, especially in the direction of increasing their ability to self-healing. The efficiency of protection and mechanical properties of silicide coatings are increased by introducing modifying elements $\mathrm{B}, \mathrm{Fe}, \mathrm{Be}, \mathrm{Cr}, \mathrm{Ti}, \mathrm{V}, \mathrm{Ta}, \mathrm{W}$, Mo [3].

Boron doping of silicic coatings has become widespread [8]. The technological process can be carried out in one step when using as a diffusion source a powder mixture containing compounds Si and B. Barrier properties of boride phases allow to form on niobium borosilicide coatings with different arrangement of boride and silicide layers, thus providing its specified physicochemical properties [5].

Therefore, the gradual formation of borosilicide coating is a flexible technological process that allows you to control the structure of the multilayer coating [7]. A morphological model of two-stage processes of complex coatings on niobium is proposed [4].

Unmodified diffusion silicide coatings on niobium alloys have high heat resistance. However, the service life of such coatings and operating temperatures, especially in thermal cycling, are insufficient. In order to increase heat resistance and increase heat-fatigue characteristics, multicomponent diffusion coatings based on the Ti-Si system have been developed [9]. It is established that the activity of $\mathrm{Ti}$ and $\mathrm{Si}$ in the saturated mixture are the main controlling factors for the creation of coatings of high heat resistance. Coatings of optimal composition allowed to increase the temperature limit of heat resistance of the substrate to $2000{ }^{\circ} \mathrm{C}$.

Numerous combinations have been studied in the practice of modifying silicide coatings on niobium. To increase the heat resistance of niobium, multilayer Al-Si coatings with a thickness of $40 . .50 \mu \mathrm{m}$ were used. The two-layer coatings had a different phase composition - the inner layer $\mathrm{NbSi}_{2}$, the outer consisted of ternary compounds $\mathrm{Nb}-\mathrm{Al}-\mathrm{Si}$ [10]. In order to increase the heat resistance, the possibility of increasing the content of $\mathrm{Cr}$ and $\mathrm{Ti}$ in the silicide coating on Nb-alloys $\mathrm{BH} 2$ and $\mathrm{BH} 3$ by sequential application of diffusion sublayers by immersion in a salt melt [2]. The Ag-Si-Al system coating is patented. To increase the thermal fatigue characteristics of silicic coatings using the Co-B system. The effect of copper on borosilization of niobium, as well as the effect of copper and sulfur have been studied [7]. The joint diffusion saturation of niobium with titanium and zirconium provided a positive effect. Complex saturation with silicide provides complex structures with the main phase of $\mathrm{MoSi}_{2}$ [11]. Metal components in the powder medium provide double and triple silicides such as $\mathrm{Cr}_{1{ }^{-}} \mathrm{Fe}_{\mathrm{x}} \mathrm{Si}, \mathrm{Cr}_{1^{-}{ }_{\mathrm{x}}} \mathrm{Co}_{\mathrm{x}} \mathrm{Si}$, $\mathrm{Cr}_{1-x} \mathrm{Fe}_{\mathrm{x}} \mathrm{Si}-\left(\mathrm{Cr}_{1-\nu} \mathrm{Fe}_{v}\right)_{5} \mathrm{Si}_{3}$. Heat-fatigue characteristics are increased by silicification in a mixture of $\mathrm{TiSi}_{2}$, disilicide of metals of IV or VI groups and aluminum fluoride [3].

It should be noted the best results to date for the protection of niobium alloys - developed a method of vacuum activated diffusion saturation [12]. The method provides for the application of a complex coating on niobium when $\mathrm{Mo}, \mathrm{Ti}, \mathrm{Cr}, \mathrm{Ni}, \mathrm{Al}, \mathrm{Si}, \mathrm{B}$ are present in the reaction zone. The heat resistance of the new coatings was studied on niobium rods with a diameter of $2 \mathrm{~mm}$ and a length of $100 \mathrm{~mm}$. The coating with a thickness of about $100 \mu \mathrm{m}$ was applied at temperatures of $1423-1573 \mathrm{~K}$ and a pressure of $10^{-1} \ldots 10^{-2} \mathrm{~Pa}$. At a test temperature of $1700^{\circ} \mathrm{C}$ in air, the best results (55 hours) were shown by the coating of molybdenum borosilicides $\left[\mathrm{Mo}\left(\mathrm{Si}_{\mathrm{x}} \mathrm{B}_{\mathrm{y}}\right)_{2}\right]$, with an outer vitreous borosilicate film, which provided a self-healing effect.

Coating of niobium alloys in liquid metal melts has been used in industrial practice [13]. As transport melts, low-melting metals with the addition of alloying elements are used. The expediency of using Al-based transport melt with alloying additives $\mathrm{Si}, \mathrm{Cr}, \mathrm{Mo}, \mathrm{Ti}, \mathrm{Y}, \mathrm{Ni}, \mathrm{Zn}$, Sn has been confirmed. The most stable were multicomponent coatings obtained with the addition of Si and Cr. Apply a liquid metal melt based on $\mathrm{Na}$ with alloying additives $\mathrm{Al}$, $\mathrm{Si}, \mathrm{Ti}, \mathrm{Cr}$. Melts of refractory metals - Na, Bi, Pb, Sn, Re, $\mathrm{Zr}$, Re-Pd, Zr-Pd - are used as transport. From the $\mathrm{Na}$ melt, a platinum-containing layer was applied to the $\mathrm{Nb}$ alloy [14]. 
Of the methods of chemical-thermal treatment for surface hardening of niobium alloys used gas nitriding [15]. Special nitrided niobium alloys have been developed. The influence of alloying elements on the nitrogen content of niobium has been studied. The regularities of nitriding of niobium alloys, the influence of temperature, duration of processing and alloying elements on the structure, phase composition and hardness of diffusion layers have been studied [16]. It is established that $\beta$-nitride of the $\mathrm{NbN}$ type is formed on the surface of $\mathrm{Nb}$ alloys nitrided in the range of $600-800{ }^{\circ} \mathrm{C}$, and a more stable $v$-modification of the nitride of the same type is formed in the range of 900 $1000{ }^{\circ} \mathrm{C}$. Under the surface nitride layer is a thin layer of nitride $\mathrm{Nb}_{2} \mathrm{~N}$, and behind it - a zone of solid solution $\mathrm{N}_{2}$ with inclusions of nitrides in $\mathrm{Nb}$ alloying elements. Doping of Mo, Ti and $\mathrm{Zr}$ leads to an increase in hardness directly under the nitride layer and to a decrease in the thickness of the nitrided layer. Nitriding was carried out in a wide temperature-time range and ambient pressures - at temperatures of $600-1300{ }^{\circ} \mathrm{C}$ and exposure for 15 minutes 52 hours. The best results were obtained at $800{ }^{\circ} \mathrm{C}$ and a nitriding duration of 15 minu-tes [17].

It should be noted a series of studies on the effects of nitrogen-containing media on niobium $[18,19]$. Note the significant increase in resistance to oxidation at high temperatures. The nature of the chemical bond in niobium nitride is such that these compounds have a metal-like structure, ie, along with covalent metal-nitrogen bonds, they partially retain metal-metal bonds, which give stability to the crystal lattice [19].

Coated on niobium from the gas and solid phases [18]. The gas phase was ammonia, and the solid phase was powders containing Si and Al. This treatment made it possible to obtain complex multilayer coatings. Of the solid-phase reagents, the greatest action was caused by the combined action of ammonia and a mixture of $\mathrm{SiC}+\mathrm{SiO}_{2}$.

The thermal stability of the nitrided layers was evaluated by the effect of the duration of vacuum annealing. The thickness of the diffusion zone of the nitrided layer is determined by the simultaneous flow of two processes: saturation of the alloy with nitrogen due to diffusion from the surface and impoverishment of the alloy with nitrogen as a result of desorption of $\mathrm{N}$ from the sample surface. An analytical expression of the dependence of the thickness of the diffusion zone in the alloy $\mathrm{MN}-1$ on the time of vacuum annealing is proposed. The maximum thickness of the diffusion layer for the alloy MN-1 was $280 \mu \mathrm{m}$ with nitriding at $800^{\circ} \mathrm{C}$, for 3 hours and vacuum annealing for 1 hour at $1100{ }^{\circ} \mathrm{C}[5]$.

The effect of previous plastic deformation on the nitriding kinetics of niobium alloys was investigated. The degree of compression $\varepsilon$ was $25 . .90 \%$. It was found that the thickness of the nitride zone and the zone of internal nitriding is extremely dependent on $\varepsilon$, reaching the maximum values of $\varepsilon=25 \ldots 50 \%$ for different alloys [4].

The tendency of transition from gas nitriding to ionic nitriding in the glow discharge is also observed during the strengthening of niobium alloys [20]. Ion nitriding temperature $1000{ }^{\circ} \mathrm{C}$, duration up to 5 hours, gas pressure $4 . .13 \mathrm{~mm} \mathrm{Hg}$.

New possibilities of strengthening niobium alloys are opened by the technology of thermocyclic ionic nitriding [21]. The peculiarities of this technology are that the thermocyclic mode creates thermal stresses in the surface layer, which accelerate diffusion. The cyclic mode of heating by a glow discharge provides necessary temperature only in a surface layer of a detail without heating of a core. The effect of anomalous mass transfer under the action of thermal stresses accelerates the diffusion of nitrogen 3 times. The thermocyclic mode with heating of only a surface layer provides reduction of energy consumption to 10 times in comparison with the classical isothermal mode. However, the main advantage of the thermocyclic regime of HTO is to improve the quality of the coating by grinding the grain size more than 2 times. Microhardness increases by $20 \%$, the hardness gradient decreased by more than 3 times. Reducing the hardness gradient reduces the level of stress concentration under reduced loads.

Glow discharge treatment is also used to silicify niobium. Saturation was performed in anhydrous $\mathrm{Si}+\mathrm{SiCl}_{4}$ medium in a closed-volume system at a pressure of $10 \mathrm{~mm}$ $\mathrm{Hg}$. for 1 hour at temperatures up to $1400^{\circ} \mathrm{C}$.

Known works on high-temperature cementation of niobium, but they have not found industrial application [22]. The process of nitrocementation of niobium spring alloys in melts of $\mathrm{KNCO}$ and $\mathrm{K}_{2} \mathrm{CO}_{3}$ salts is available in industrial application.

Traditional enameling and slip-diffusion coatings are used to protect niobium alloys [1]. In the literature, this technology is called the method of surfacing. Powders of the $\mathrm{Si}-20 \mathrm{Cr}-5 \mathrm{Ti}$ and $\mathrm{Si}-20 \mathrm{Cr}-20 \mathrm{Fe}$ system on a varnish basis with vacuum firing at a temperature of $1370{ }^{\circ} \mathrm{C}$, glass enamels of the $\mathrm{Al}_{2} \mathrm{O}_{3}-\mathrm{SiO}_{2}-\mathrm{P}_{2} \mathrm{O}_{5}-\mathrm{BaO}$ composition are used. The powder was applied by electrophoresis. Note the high efficiency of slip coatings. The $\mathrm{MoSi}_{2}$-based coating works at $1400^{\circ} \mathrm{C}$ in air for 300 hours, the $\mathrm{Si}-\mathrm{Cr}-\mathrm{Fe}$ composition coating at $1550{ }^{\circ} \mathrm{C}$ worked for 4 hours and withstood 553 heat change cycles. Heat resistance and heat resistance up to $1900^{\circ} \mathrm{C}$ have coatings on niobium, obtained by diffusion militia of baked layers of Mo - $(0,5 \ldots 1,5) \mathrm{Pd}[1]$.

Gas-thermal plasma spraying is used to protect niobium alloys [1]. The coating of the Si-Ti-Mo system protects niobium from oxidation in the temperature range $1300-1400{ }^{\circ} \mathrm{C}$. In the range of $1200 \ldots 1600{ }^{\circ} \mathrm{C}$ workable coating system Hf-Ti-Mo-Nb-silicides with additives of carbide and boride $\mathrm{Ti}$ stoichiometric composition. The multi-component silicide coating in a given temperature range retains more $\mathrm{Si}$-rich silicides $\mathrm{Ti}$ and provides heat resistance and ductility. The high porosity of plasma coatings limits their use in finishing operations [1]. Therefore, they are used in multi-operational technologies as aids. However, to protect niobium and its alloys, physicochemical bases for the creation of special heterophase alloys for the formation of powders of these alloys by plasma spraying 
more effective than traditionally used, heat-resistant protective coatings have been developed. They also try to protect niobium by spark plasma sintering [23].

Known works on the protection of niobium alloys by deposition from the gas phase (PVD-method). Complex silicide coatings of the $\mathrm{NbSi}_{2}-\mathrm{MoSi}_{2}$ type were applied by vacuum-plasma deposition [24]. These coatings worked for 10 hours at $1400{ }^{\circ} \mathrm{C}$ in air. Multilayer coatings based on $\mathrm{MoSi}_{2}$ were applied by magnetron sputtering [25]. Limits the use of PVD-methods in the protection of niobium in the presence of the droplet phase, which leads to defects in the coating. The application of Mo by vacuum-plasma method with subsequent silicification did not lead to a significant increase in heat resistance due to the presence of a droplet component [26].

The use of separators in PVD devices has avoided the formation of a droplet phase [42]. This significantly expands the possibilities in the application of promising technologies in the application of multilayer coatings on niobium alloys.

The possibilities of laser technology for coating niobium have been investigated. Laser technology is used for applying metal sublayers for applying silicide coatings. Laser pulses donate tungsten to the surface of niobium. Aluminide and silicide coatings were applied by laser treatment of a mixture of $\mathrm{Al}$ and Si powders [27].

A number of disadvantages prevent the widespread use of protective coatings. To overcome them, there is a tendency to develop multi-operational technologies. The combination of several technological techniques in one process improves many properties of coatings. The trend in the development of multi-operational technologies has developed with the strengthening of niobium alloys. Thus, laser technology is the finishing touch in the formation of dense coatings such as $\mathrm{ZrO}_{2}-\mathrm{Y}_{2} \mathrm{O}_{3}$ after slip, plasma and diffusion treatment of niobium [27].

The multicomponent coating of type $(\mathrm{W}, \mathrm{Mo})(\mathrm{Si}$, Ge) ${ }_{2}$ was obtained by a two-stage process comprising a vacuum-plasma layer of Mo-30\% W with a thickness of 50-5 $\mu \mathrm{m}$, followed by diffusion saturation of $\mathrm{Si}$ and $\mathrm{Ge}$ from a powder mixture containing $\mathrm{NaF}$ activator. Ge additives increase the heat resistance of the coating by increasing the CTE of the $\mathrm{SiO} 2$ film. The coating withstood 60 thermal cycles with a maximum temperature of $1540^{\circ} \mathrm{C}$ [28]. Diffusion coating of $\mathrm{Cr}-\mathrm{Ti}-\mathrm{Si}$ was applied to the sublayer of $\mathrm{MoSi}_{2}$, applied by the plasma method. Composite coatings such as Mo-nitrides of molybdenum were obtained by nitriding gas-thermal spraying of Mo. The effect of heat treatment (annealing in air) on diffusion coatings of the $\mathrm{B}_{4} \mathrm{C}-\mathrm{TiSi}_{2}$ type and on the $\mathrm{MoSi}_{2}-\mathrm{B}_{4} \mathrm{C}$ plasma coating was investigated. Silicidal coating with additives Mo-Ti$\mathrm{Al}$, obtained by a combination of diffusion and plasma methods, was treated by annealing in the temperature range $1200-1500{ }^{\circ} \mathrm{C}$.

The development of technologies for strengthening niobium is accompanied by a study of the complex properties of coatings. Metallographic, X-ray diffraction, micro-
X-ray spectral analyzes and DTA investigated the effect of various alloying elements on the properties of coatings. One of the tasks when choosing alloying elements is to reduce the temperature of formation of slip coatings.

The main task is to protect niobium from high-temperature high-intensity oxidation. However, up to $800^{\circ} \mathrm{C}$ solid solutions of oxygen in niobium are formed, above $800^{\circ} \mathrm{C}$ oxides are formed, which are easily separated from the metal [1]. Therefore, low-temperature [29, 30] and high-temperature oxidation of niobium [1] are investigated. An increase in the fragility of niobium with oxygen has been established, even the term "catastrophic increase in the fragility of the material" is used [29]. Structural changes in the surface layer caused by oxygen saturation can determine the level of mechanical properties of the material. The depth of the saturation zone is determined by microhardness, based on the dependence of this characteristic on the concentration of oxygen in niobium [29]. The change in oxygen concentration in niobium was determined by the method of internal friction, the lattice period. Microhardness and ductility under bending at a temperature of $785^{\circ} \mathrm{C}$ and air pressure of $10^{-4} \mathrm{~mm} \mathrm{Hg}$. After 5 hours, the plasticity of niobium decreases sharply, at 20 hours - drops to zero. We studied the increase in the brittleness of niobium with oxygen at low strain rates in the temperature range $77 \ldots 1100 \mathrm{~K}$ and in the range of strain rates in tensile strength $5 \cdot 10^{-5} \ldots 2 \cdot 10^{-1} \mathrm{sec}^{-1}$. Therefore, the effectiveness of heat-resistant coatings on niobium is also determined by their resistance at normal temperatures, which eliminates oxygen saturation. Even the allowable low temperature limit of operation is set to avoid increasing the fragility of the material [31].

The thermal stability of niobium coatings was evaluated by changes in the structure and composition of the coating, as well as the kinetics of formation and structure of intermediate phases in the interaction of coatings with $\mathrm{Nb}$-substrate in wide temperature-time intervals in oxidizing media and in vacuum [5].

Sufficient attention is paid to the determination of elastic permanent coatings on niobium [25]. Note the high damping properties of coatings on niobium, which are provided by the porous structure of the coating [32].

A significant disadvantage of protective coatings is the reduction of strength and ductility of the base material. This disadvantage is inherent in coated niobium alloys. Despite the large number of studies, there is no clarity on this issue. Difficulties in explaining the contradictions are caused by differences in the method of coating and their testing. A wide range of combinations of base materials and coatings, a variety of application technologies do not allow to compare a number of results and draw generalized conclusions. In practice, protective coatings are forced to put up with the phenomena of reducing the initial strength and ductility. At least for the sake of preservation of heat resistance in the oxidizing environment.

For niobium alloys VN-3, the coating coating showed a decrease in the level of mechanical properties 
both at room temperature and at $1100{ }^{\circ} \mathrm{C}$. A particularly strong decrease in $\sigma \mathrm{b}$ (up to $40 \%$ ) at $1100^{\circ} \mathrm{C}$ was detected on samples with a complex coating of the $\mathrm{Cr}$-Ti-Si diffusion layer with the $\mathrm{MoSi}_{2}$ sublayer applied by the plasma method. The short-term strength and ductility of the 5VMC niobium alloy with a slip coating of the $\mathrm{MoSi}_{2}-\mathrm{HfSi}_{2}$ type in vacuum, inert medium and in air in the temperature range $290 \ldots 2070{ }^{\circ} \mathrm{C}$ are determined. The coating reduced the strength characteristics of the $\mathrm{Nb}$ alloy by $10 . . .40 \%$ in almost the entire temperature range studied. The plastic properties of the composite are $1,5 \ldots 4$ times lower than the properties of the base. Similarly, the strength and ductility decreased during the tests in the initial state, after annealing and when applying a silicide-ceramic coating in the temperature range $290 \ldots 2270 \mathrm{~K}$ in vacuum, inert medium and in air [34]. Al-Cr-Si and Al-Cr-Si-Ti coatings do not change the strength of the NCU alloy at room temperature, but reduce it at $1100^{\circ} \mathrm{C}[33,34]$.

During tensile tests of the VN-3 alloy, an increase in brittleness with a simultaneous decrease in the tensile strength was observed in the temperature range of $500 \ldots 700^{\circ} \mathrm{C}$, which is associated with gas saturation of the surface. The increase in the brittleness of the alloy VN$2 \mathrm{AE}$ after contact in the solid phase with graphite and industrial insulation at $1373 \mathrm{~K}$ and a duration of 103 hours in argon and vacuum was investigated. Silicidal coatings protected the alloy from brittle fracture, although reduced the initial mechanical properties. Criteria for determining the strength and plastic properties of the composite depending on the structural state have been establishhed [31].

In [46], the decrease in the initial strength and deformability of the base during coating is explained by the transition of the crack through the adhesive layer of the brittle coating layer. Therefore, the main factor is the strength of the adhesive bond. The criterion of strength of the "base-coating" system sets the value of the maximum allowable adhesive strength from the condition of stopping the crack.

The creep resistance of $\mathrm{Nb}$-alloys with silicide coatings in the temperature range of $1426 \ldots 1760{ }^{\circ} \mathrm{C}$ was defined as the stress causing deformation equal to $2 \%$ for $1 . .60$ minutes The creep and long-term strength on small temporary bases of 5VMC alloy with silicide coating in the temperature range $1770 \ldots 2020 \mathrm{~K}$ were studied. The values of creep limit on tolerance of 0.5 and $1.0 \%$ of residual deformation on the basis of 0.1 were obtained; 1.0 and 10 hours at a temperature of 1770,1970 and $2020 \mathrm{~K}$ in vacuum, inert medium and in air. It was found that the characteristics of heat resistance in a protective environment are lower than in air, and the creep resistance in a protective environment is higher than in tests in vacuum [35].

Note a number of positive effects in the nitriding of niobium alloys. The value of the modulus of elasticity $E$ of nitrided niobium alloy increases with increasing both temperature and nitriding time. The elastic limit with increasing nitriding time increases by $3 \ldots .5$ times. With increasing nitriding temperature, the value of the tensile strength monotonically increases by $1,5 \ldots 2,0$ times, and the value of the relative elongation decreases monotonically when tested at room temperature [36].

Increasing the nitriding temperature from 1100 to $1500{ }^{\circ} \mathrm{C}$ at a holding time of 1 hour increases the hardness of niobium alloys from 1400 to $2000 \mathrm{~kg} / \mathrm{mm}^{2}$. The tensile strength of pure niobium increases by $25 \ldots 30 \%$ at $800{ }^{\circ} \mathrm{C}$ and has almost no effect on heat resistance at $1000^{\circ} \mathrm{C}$. And for the alloy $\mathrm{VN}-3$ tests for creep and long-term strength at $900 \ldots 1400{ }^{\circ} \mathrm{C}$ showed an increase in the time to failure and improve the characteristics of creep resistance by $1,3 \ldots 2,5$ times do not lead to a decrease in ductility [36].

The increase in heat resistance of niobium alloys is explained by the stabilization of processes occurring in the volume and at the grain boundaries due to the release of dispersed nitride particles. The increase in heat resistance is associated with coherent dispersed nitride phases released in the grain volume and at their boundaries, as well as in the form of individual chains at the boundaries of the blocks. The composition of the selection is defined as nitride $\mathrm{Nb}$ and $\mathrm{Zr}$ [36].

A significant disadvantage of nitriding niobium alloys is the increase in the fragility of the diffusion layers [36]. One of the reasons for the fragility of the alloy at room temperature after nitriding is the segregation of gaseous impurities at the grain boundary and in the boundary volumes, which causes increased microhardness of the boundaries. One of the reasons for the fragility of nitrided $\mathrm{Nb}$ alloy may be treatment with ammonia [19]. Set nitriding modes that provide the optimal combination of propertyes [36].

Insufficient heat resistance and heat fatigue of coatings on $\mathrm{Nb}$-alloys are noted $[9,12]$. The change of the main mechanical characteristics of the coated niobium alloy depending on the number of heating cycles up to $1315^{\circ} \mathrm{C}$ at a pressure of $3 \ldots 5 \mathrm{~mm} \mathrm{Hg}$ is shown. [33].

The range of experimental means for testing coatings on niobium alloys is quite wide - from nano- and microindentation [37] to multi-parameter bench tests. It should be noted that the state of experimental means for determining the properties of coatings is characterized by a great variety and difference of test methods, shapes and sizes of samples, test modes, methods of heating and cooling.

\section{Research methodology}

The method of accelerated testing of materials with heat-resistant coatings in air under conditions of thermocyclic creep is used. In Ukraine, this technique is standardized [38]. The main damaging factor is abrupt cyclic heat changes. Continuous recording of the creep curve characterizes all changes in the coating and in the area of adhesive contact with the substrate until the destruction of the sample.

The trend in the development of high-temperature tests is the transition from isothermal to thermocyclic regimes. In thermocyclic tests, the rate of oxidation in air is 
significantly higher than in isothermal [39]. This fact allows to reduce the duration of tests and serves as a basis for the creation of accelerated test methods for coatings. An advanced direction in the testing of coatings is the use of methods of thermomechanical fatigue - TMF [40, 41]. The new technique simulates the simultaneous action of operational factors: mechanical load, high temperatures, sudden heat changes, oxidizing environment. The non-additivity of the strengthening effect requires testing under the simultaneous influence of operational factors. This is the only way to get the most reliable information about the properties of coatings.

The technique is implemented in the laboratory installation "Shchelkunchik" [42]. A distinctive feature of the installation is the heating and cooling of the sample by focusing the radiant energy in an optically closed cavity with cold mirror walls. Radiant heating, in contrast to the methods of heating by direct transmission of electric current through the sample and heating with high frequency currents (microwave) eliminates the effect of electroplastic and magnetoplastic effects. These effects lead to errors of tens of percent in determining the strength and ductility. Accelerated cooling of the sample is carried out by focusing its own thermal radiation on the absorber [42]. The advantages of cooling by focusing its own radiation is the lack of direct contact of the sample with the cooling medium, which ensures uniform cooling around the perimeter and height of the sample, and increases the cooling rate due to the absence of film and bubble boiling. Contactless cooling completely eliminates the erosion, corrosion and adsorption effects of the cooling medium.

The cold mirror walls of the optical camera provide minimal thermal inertia. This makes it possible to achieve high rates of heating and cooling. An excellent ability of the installation is the possibility of continuous visual inspection of the condition of the sample during the tests. Illuminated by radiant energy, the sample is convenient for observation through a hole in the mirror wall of the optical device. Photographing the sample during the tests allows to obtain data on the deformation of the sample, the occurrence of defects and cracks on the surface, their size, the distance between them. Photography captures the moments of cracks in the coating, its peeling. In the complex, such a survey gives an idea of the kinetics of deformation of the sample until its destruction. The condition for normal operation of parts made of niobium alloys is to ensure a minimum level of plastic deformation, as well as the minimum rate of their accumulation. Therefore, the characteristics of isothermal and thermocyclic creep during stretching of sheet five-fold samples of niobium alloy NCU with a thickness of $1 . .2 \mathrm{~mm}$ are accepted as criteria.

As a result of tests the creep curve or the diagram of short-term stretching was constructed. The thermocyclic creep curve was constructed in the form of a circumferential maximum deformation peaks per cycle. The creep curves determined the relative deformation at failure $\left(\varepsilon_{\mathrm{p}}\right)$ and the time to failure of the sample $\left(\tau_{\mathrm{p}}\right)$, as well as the minimum creep rate. The creep curve was also used to determine deformations when defects appeared in the coating.

The installation is equipped with a computer system for control and registration of parameters [43].

The advantages of multi-operational technology are shown in [47] by comparing the boundary deformations, creep rate and durability in the isothermal and thermocyclic modes of the three coating options shows the advantage of combined plasma-diffusion coating over silicide and borosilicide coatings.

The installation is equipped with a computer system for control and registration of parameters [43].

The advantages of multi-operational technology are shown in [47] by comparing the boundary deformations, creep rate and durability in the isothermal and thermocyclic modes of the three coating options shows the advantage of combined plasma-diffusion coating over silicide and borosilicide coatings.

A complex coating with a plasma sublayer of $\mathrm{MoSi}_{2}$ with diffusion saturation of the surface layer with elements, the main of which are Si and B, was shown to be a multiple advantage.

Diffusion saturation of all three variants was performed in vacuum. To study the effect of stress level in the process of creep, the test was performed in the stress range of $40 \ldots 70 \mathrm{MPa}$. This made it possible to construct longterm strength curves, the dependence of the minimum creep rate on stresses, as well as creep limits and long-term strength limits.

Isothermal tests were performed at a temperature of $1400{ }^{\circ} \mathrm{C}$ in air [42], thermocyclic in the mode of $1400 \leftrightarrow 250{ }^{\circ} \mathrm{C}$ at a heating time of $20 \mathrm{~s}$ and cooling of $60 \mathrm{~s}$ in a single cycle.

When plasma-diffusion application on the surface of the niobium alloy formed a multilayer coating. The highly porous plasma-sprayed layer of molybdenum silicide has a significant variation in thickness $(\mathrm{h}=100 \ldots 350 \mu \mathrm{m}$, $\left.\mathrm{H}_{\mu}{ }^{20}=6880 \mathrm{MPa}\right)$ [47].

When studying the microstructure of samples with plasma-diffusion coating after testing, it was found that cracks in the coating are formed in the process of creep mostly at the interface between the plasma and diffusion layers of the coating. The center of their origin are individual imperfections in the diffusion layer in the state of delivery. The spread of cracks occurs in both plasma and diffuse layers of the coating. Inhibition of the growth of cracks in the plasma layer is due to the rounded nature of the pores and increased plasticity of this layer. The growth of cracks deep into the sample is usually inhibited by the boride sublayer [47].

It is observed that the penetration of atmospheric oxygen occurs through a crack that has reached the surface of the coating in its development, and causes a predominant oxidation of the diffusion silicide layer. This phenomenon is especially characteristic of samples with significant durability. Thus, almost always this effect is manifested at low levels of load (Fig. 1, c) 
In [44], the functional dependence of the adhesive strength, residual stresses and critical deformation of the substrate on the thickness of the coatings is presented, as well as the scatter of the thickness of the silicide coatings is noted. It was found that the dependence of durability on the thickness of coatings on niobium alloys is extreme [5]. Therefore, the thickness of the coatings as a necessary component of their performance, deserves some research and its optimization, it is necessary to pay more attention, conducting some in-depth tests.

The study of the composition included observation of the surface of the samples during the tests.

At the necessary deformations $(\varepsilon \geq 6 \%)$ a grid of cracks appears on the surface of the samples. Next, the weight of the crack begins to unfold, which indicates a uniform distribution of deformation along the length of the working part of the sample. Drops of fusible compounds appear on the surface of the coating. When approaching the third stage of creep, when the opening of the cracks becomes large enough, in the mouth of the cracks is well visible the beginning of the boiling of these melts. The distribution of joints fills all cracks almost completely, preventing the penetration of aggressive gaseous media into the coating. In addition, this melt has healing properties, inhibiting the opening of cracks. In this case, at elevated temperatures, the multifunctional capabilities of the plastic melt - containment, corrosion and mechanical destruction. Consideration of the kinetics of deformation of the studied composition during one heating cycle allowed us to conclude that this phenomenon is most pronounced in thermocyclic creep [47].

The advantage of plasma-diffusion coating over silicide, borosilicide single-stage coatings is manifested in the increase of durability at isothermal creep in air $\left(1400{ }^{\circ} \mathrm{C}, 50 \mathrm{MPa}\right)$ in $1,9 \ldots 3,7$ times, and at thermocyclic creep, $\left(1400 \leftrightarrow 250{ }^{\circ} \mathrm{C}, 50 \mathrm{MPa}\right)$ in $6,8 \ldots 8,5$ times [47].

A promising direction in the development of protection of niobium alloys is the creation of multilayer heatprotective coatings with an outer ceramic layer. Sufficient experience has been gained in applying heat-protective coatings on heat-resistant nickel alloys. However, a significant limitation is the limitation of the thickness of the outer ceramic layer due to insufficient adhesive strength.

A significant reserve in increasing the thickness of the ceramic layer with sufficient adhesive strength is the development and application of a discrete structure [48]. This reduces the stress concentration both in the area of adhesive contact and in the coating layer, which greatly increases the durability in operating conditions.

The main characteristic of a discrete structure is the distance between two adjacent cracks. Therefore, the measurement of crack density in creep is used when coating a discrete structure.

Minor changes in the nature of the destruction of the plasma-diffusion coating were detected when comparing the creep of the samples at different load modes. The first

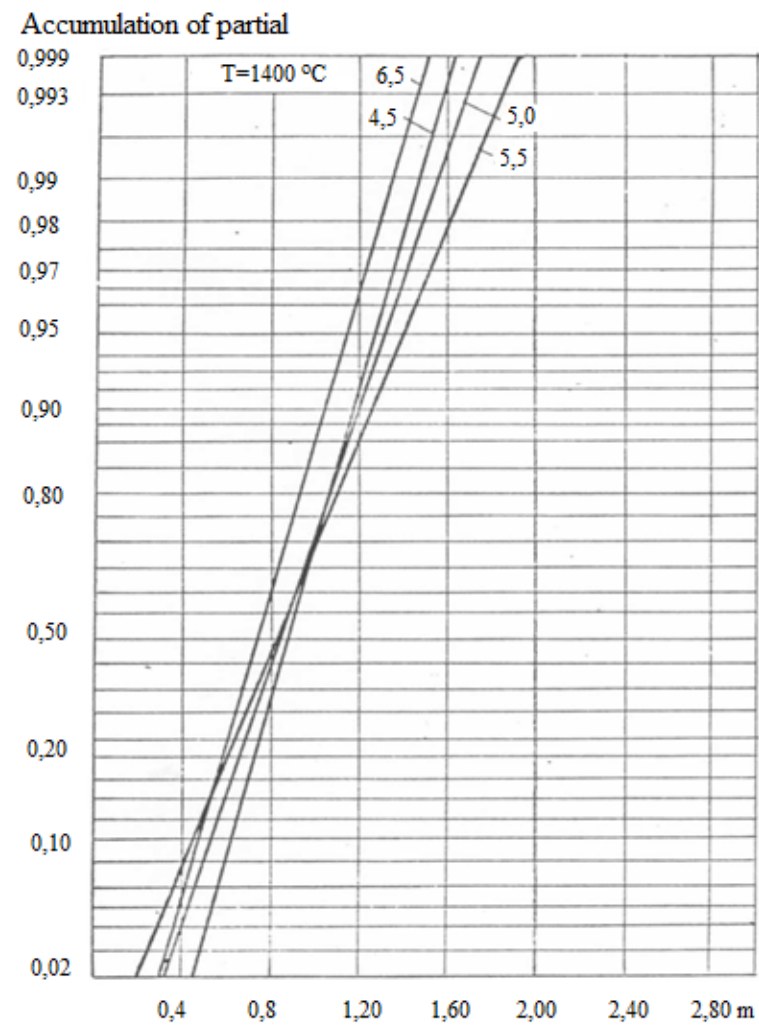

Fig.1. Probability curve distribution curves in the plasma-diffusion coating formed during isothermal creep at different load levels. $\mathrm{T}=1400{ }^{\circ} \mathrm{C}$

visible cracks on the surface of the coating in the thermocyclic test mode appear at the levels of relative creep deformations of $4 . . .5 \%$, and in the isothermal mode $-5 \ldots 7 \%$. This difference is probably due to the change in the plasticity of the coating depending on the temperature (in the thermocyclic mode, the average temperature is lower than in isothermal). However, changes in the density of the cracks obtained in the coating were not detected. Fig. 1 and Fig. 2 show the probability curve pitch curves that occur in the coating on the surface of the samples after, respectively, isothermal and thermocyclic tests. As can be seen from the figures, this parameter at a level of $50 \%$ probability ranges from 0,75 to $0,95 \mathrm{~mm}$. A slight slope of the probability curves indicates a small scatter of the crack pitch values along the length of the working part of the samples.

To apply a discrete coating structure, choose a grid pattern taking into account the crack density in a traditional continuous coating. The grid template is placed in the chamber of the vacuum-plasma installation at an adjustable distance from the surface of the reinforced product (Fig. 3) in the path of the ionized flow.

In the study of the microstructure of samples with plasma-diffusion coating after testing, it was found that cracks in the coating arise in the process of creep mostly at the interface between the plasma and diffusion layers of the coating [47-51]. 


\section{Accumulation of partial}

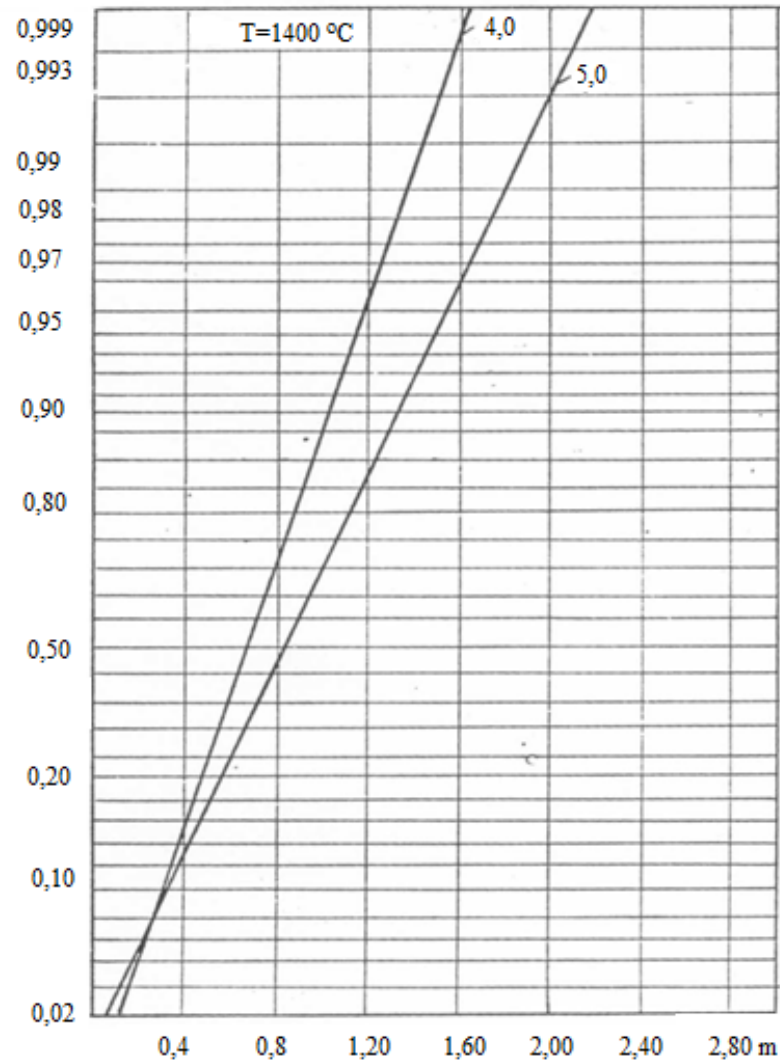

Fig.2. Probability curve distribution curves in the plasma-diffusion coating formed during thermocyclic creep at different load levels

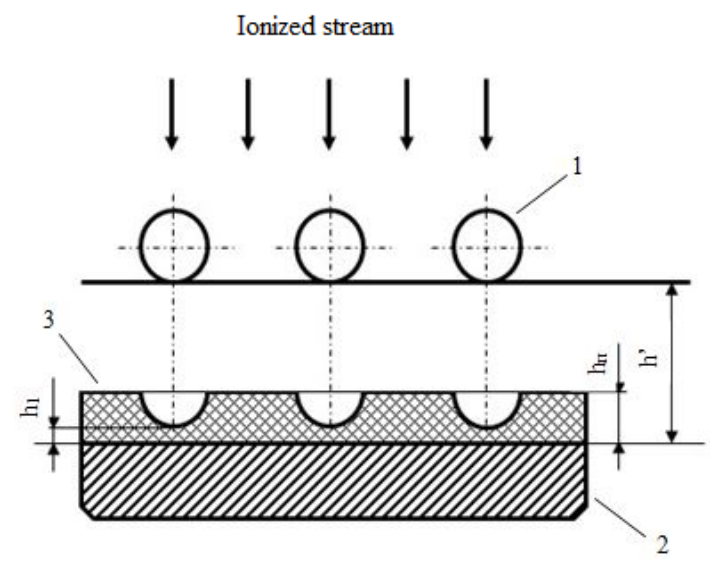

Fig.3. Grid pattern: 1-grid, 2-base material, 3-coating

Inhibition of the growth of cracks in the plasma layer is due to the rounded nature of the pores and the increased plasticity of this layer. The growth of cracks deep into the sample is usually inhibited by the boride sublayer.

Penetration of atmospheric oxygen occurs through a crack that has reached in its development of the coating surface, and causes the predominant oxidation of the diffusion silicide layer. This phenomenon is especially characteristic of samples with significant durability. Thus, almost always this effect is manifested at low load levels (Fig. 1, c) and, most often, is absent at voltages above $50 \mathrm{MPa}$ [47-51].

The choice of coating material, method of application and experimental means for determining the properties of coatings is characterized by great variety and difference. Numerous test methods from nano- to microindentation to multiparameter bench tests. There is a great variety and difference of forms and sizes of samples of modes of drawing and tests, methods of heating and cooling.

Therefore, it is not possible to compare the results of individual studies. The results of determining the properties of coatings are incompatible due to the variety of structural schemes of coatings, the ratio of the thickness of the different layers, the difference in application technologies and methods of surface preparation. A brief review and analysis of the work indicates the relevance of creating protective coatings on niobium alloys. However, the growing number of studies and publications does not clarify the solution to this difficult problem.

\section{Conclusions}

1. Practically all considered developments and methods provide with this or that efficiency of the decision of concrete problems at protection of the basic material against high-temperature influence. In this regard, applied research in this area are relevant and priority at the present stage.

2. To increase the durability and thermomechanical characteristics of niobium alloys in an oxidizing environment, the most effective is to use the technique of multifactorial experiment with multicriteria optimization, which reflects the diversity, interdependence of physicochemical and mechanical phenomena affecting thermoprotective properties.

3. The most significant increase in thermomechanical characteristics using multi-operational technologies. Niobium has a feature that must be taken into account when applying the coating - the modulus of elasticity is 3 times less than that of alloy steels and nickel alloys. Usually coatings on niobium alloys are high-modulus layers of cermets. Differences in modulus of elasticity reduce the strength of the coating on a deformed basis. To increase the modulus of elasticity of the niobium alloy before applying a multilayer coating, it is necessary to use the operation of chemical heat treatment.

4. Multi-operational technologies allow to apply multilayer coatings from different structural schemes - by choosing and optimizing the ratio of thickness, adhesive strength and elastic properties of individual layers, achieve preservation of initial strength and deformation after coating by limiting and stopping "sharp" cracks in layers. 
5. The most reliable and comparable thermomechanical characteristics of niobium alloys in an oxidizing medium provide tests on standard samples for isothermal and thermocyclic creep. A distinctive feature of this technique is the heating and cooling of the sample by focusing the radiant energy in an optically closed cavity with a cold mirror glass. Radiant heating, in contrast to the methods of heating by direct transmission of electric current through the sample and heating with high-frequency currents eliminates the effect of electro- and magnetoplastic effects.

6. The trend of development of chemical-thermal treatment processes in powder mixtures, salt and metal melts ends in the transition to vacuum processes. The most promising in terms of productivity and low energy consumption is the technology of thermocyclic ionic nitriding. The use of cyclic heating and cooling accelerates diffusion due to thermal stresses. This reduces the processing time by 3 times and energy consumption by 10 times due to surface heating only. The microhardness of the coating is $20 \%$ higher than with traditional isothermal HTO. The viscosity of the coating increases by reducing the grain size by 2 times, the hardness gradient decreases by $3 . . .4$ times.
7. The advantage of plasma-diffusion technology provided increased plasticity of the coating, the presence of thin barrier sublayers, discontinuous structure of the coating, the presence of low-melting compounds that help heal defects in the coating, increase its corrosion resistance and resistance to thermal fatigue. The combination of these properties allowed to provide increase in durability in comparison with silicic and borosilicidal coverings in the conditions of isothermal creep in air $\left(1400^{\circ} \mathrm{C}, 50 \mathrm{MPa}\right)$ $1,9 \ldots 3,7$ times and in the conditions of thermocyclic creep $\left(1400 \leftrightarrow 250^{\circ} \mathrm{C}, 50 \mathrm{MPa}\right)$ in $6,8 \ldots 8,5$ times.

8 . The difference in the characteristics of creep and long-term strength of the three variants of coatings is also explained by the nature of the development of cracks in the coating. The transition from single "sharp" cracks in the coating to regular cracks in the diffusion sublayer with rounded vertices provides an increase in the strength and durability of niobium alloys.

9. The use of a discrete structure, taking into account the crack density of the traditional continuous coating with creep, will increase the thickness of the ceramic layer in the heat-protective coatings and increase their performance

\section{References}

[1] A.I. Borisenko, S.V. Khashkovsky, Protection of products from niobium alloys from high-temperature gas corrosion, Nauka, 1986. https://doi.org/10.1007/BF00843017

[2] Yu.V. Dzyadykevich, "Heat-resistant coatings on niobium and alloys based on it", Powder metallurgy, no. 1, pp. 45-52, 1986. https://doi.org/10.1007/BF00843017

[3] Yu.V. Dzyadykevich, Protection of niobium and its alloys from oxidation, USSR Academy of Sciences, no. 3, pp. 187-190, 1987.

[4] Yu.V. Dzyadykevich, "Protective coatings on niobium, tantalum, molybdenum and tungsten to increase resistance and hightemperature oxidation", Powder metallurgy, no. 4, pp. 37-42, 1992.

[5] Yu.V. Dzyadykevich, "Increasing the heat resistance of refractory metals", Inorgan. Mater, no. 11, pp. 1405-1408, 1994.

[6] Yu Jiadou, "Oxidation resistant coatings on refractory metals", Actual Probl. Mod. Mater. Sci.: 1St Russ. Chin. Symp, pp. 88-89, 1992.

[7] Yu.V. Dzyadykevich, N.I. Zablotskaya and M.V. Luchka "Influence of technological factors on the process of saturation of refractory metals with boron”, Powder Metallurgy, no. 7, pp. 70-75, 1991.

[8] Li Xiaoxia, Zhou Chungen, "Development and oxidation resistance of B - doped silicide coatings on Nb-based alloy", Corros. Sci. and Technol, no. 4, pp. 233-236, 2008.

[9] A.V. Kasatkin, "Titanosilicide diffusion heat-resistant coatings on niobium”, Aviakosm. tech. and technology, no. 1, pp. 13-17, 2007.

[10] S. Majumdar, et al., "Development of multilayer oxidation resistant coatings on niobium and tantalum", Surface and Coat. Technol, no. 12, pp. 3713-3718, 2006. https://doi.org/10.1007/BF00843017

[11] Xiao Lai-Gong, et al., "Silicidal coatings on niobium alloys obtained by complex saturation in powders", J. Aeron. Mater, no. 4, pp. 36-41, 2007.

[12] V.I. Zmiy, S.G. Rudenky, M.Yu. Bredikhin and V.V. Kupchenko, "Heat-resistant coatings on niobium and its alloys", Powder Metallurgy, no. 3/4, pp. 123-129, 2008.

[13] O.S. Tsvikilevich and V.I. Stepanishin, "Influence of preliminary boring on heat resistance of 5VMC alloy with silicide coatings", Phys.-Chem. fur. Mater, no. 4, pp. 17-20, 1988. https://doi.org/10.1007/BF00720639

[14] A.A. Sharapov, O.A. Bannykh, and E.N. Sheftel, "Features of diffusion saturation of niobium alloy with a plate of liquid sodium", Metals, no. 4, pp. 191-194, 1992.

[15] T.A. Panayoti, "Influence of hardening and aging on the resistance to small plastic deformations of nitrided niobium and its alloy MN-1", Metalloved. and term. processing. met., no. 7, pp. 33-36, 1995.

[16] V. Buscaglia, et al., "Nitridation of niobium - $46 \mathrm{wt} \%$ titanium alloy in nitrogen at $1300^{\circ} \mathrm{C}$ ", Alloys and Compounds, no. 226, pp. 232-241, 1995. https://doi.org/10.1016/0925-8388(95)01614-7 
[17] V. Buscaglia et al., "Growth of ordered lamellar precipitates during mitridation of $\mathrm{Nb}-10 \mathrm{at} \% \mathrm{Ti}$ at $1300{ }^{\circ} \mathrm{C}, \mathrm{J}$. Alloys and Compounds, no. 1, pp. 260-264, 1999. https://doi.org/10.1016/S0925-8388(98)00891-3

[18] L.P. Skuratov, et al., "Influence of high temperature and gaseous media on the creep of niobium", FHMM, no. 6, pp. 98-101, 1983.

[19] L.P. Skuratov and V.K. Yatsimirsky, "Influence of nitrogen-containing gaseous media on the physical and mechanical properties of niobium", Problems of strength, no. 12, pp.65-67, 1988. https://doi.org/10.1007/BF01528969

[20] Ito Yoshiyasu, "Kasivaya Hideo. Ionic nitriding of refractory metals", Sci., no. 4, pp. 469-474, Mach 1991.

[21] The method of surface hardening of steel parts by ion-plasma nitriding (in Ukraine ), UA. Pat. 10014, C 23 C 8/36. Dec. 15.2006.

[22] T.A. Adamyan and S.L. Kharatyan, "On the singularity of high temperature carbidization of niobium", J. Alloys and Compounds, no. 1-2, pp. 418-422, 2010. https://doi.org/10.1016/j.jallcom.2010.01.154

[23] T. Murakami, et al., "Microstructure of Nb substrates coated with Mo (SiAl) 2-Al2O3 composite and B-doped Mo5Si3 layer by spark plasma sintering", Intermetallics, no. 7-9, pp. 749-754, 2004. https://doi.org/10.1016/j.intermet.2004.02.015

[24] P.I. Glushko, V.I. Zmiy and N.F. Kartsev, "Oxidative resistance of complex silicic coatings to niobium”, Izv. USSR Academy of Sciences. Inorganic. Materials, no. 2, pp. 331-332, 1986.

[25] T.C. Chou. et al., "Mechanical properties and microstructures of metal/ceramic microlaminates. Part I. Nb/MoSi 2 Systems", J. Mater. Res., no. 10, pp. 2765-2773, 1992. https://doi.org/10.1557/JMR.1992.2765

[26] P.I. Glushko, et al., "Stability and heat resistance of silicide coatings on refractory metals. III. Stability of silicide coatings on niobium under conditions of high-temperature heating in air at 1500-1800 ${ }^{\circ}$ ", Powder. Metallurgy, no. 3/4, pp. 55-59, 2003.

[27] A.V. Kasatkin, V.A. Pitov and V.N. Polyakov, "Composite silicide oxide coatings on refractory metals", Phys. and chemistry processing. Mater, no. 6, pp. 51-57, 1995.

[28] A. Mueller, et al., "Oxidation behavior of tungsten and germanium-alloyed molybdenum disilicide coatings", Mater. Sci. and Eng. A., no. 1-2, pp. 199-207, 1992. https://doi.org/10.1016/0921-5093(92)90326-V

[29] L.I. Emelyanova and A.I. Chernitsyn "Influence of Diffusion Oxygen Saturation on the Structure of the Surface Layer and Mechanical Properties of Niobium Alloys", Probl. Strength, no. 1, pp. 74-78, 1978. https://doi.org/10.1007/BF01523700

[30] N.V Alov. "Surface oxidation of metals by oxygen ion bombardment", Nucl. Instrum. and Meth. Phys. Res. B., no. 1, pp. 337340, 2007. https://doi.org/10.1016/j.nimb.2006.12.023

[31] A.D Davydova, et al., "Mechanical properties of a niobium alloy with a molybdenum-hafnium-silicide coating", Probl. strength., no. 7, pp. 70-76, 1989. https://doi.org/10.1007/BF01529615

[32] N.I. Zarubova, Yu.P. Zotov and N.P. Kushnareva, Evaluation of the properties of the composition of the 5VMTs-silicide coating alloy by the internal friction method and chemistry of processing. Mater, no. 5, pp. 127-129, 1989.

[33] Bukhanovskii, V.V. Effect of Silicide Ceramic Coatings on the High-Temperature Strength and Ductility of Niobium Alloy of the $\mathrm{Nb}-\mathrm{W}-\mathrm{Mo}-\mathrm{Zr}$ System. Metal Science and Heat Treatment, no. 46, pp. 78-84, 2004. https://doi.org/10.1023/B:MSAT.0000029607.97403.94

[34] V.V. Bukhanovsky, et al., "High-temperature strength of niobium alloy 5VMTs with silicide-ceramic protective coating", Probl. Strength., no 2, pp. 119-129, 2004. https://doi.org/10.1023/B:STOM.0000028311.58809.f9

[35] V.V. Bukhanovsky, et al., "High-temperature strength of niobium alloy 5VMTs with silicide-ceramic protective coating. Message 2. Characteristics of the second creep", Probl. strength., no. 5, pp. 77-86, 2004.

https://doi.org/10.1023/B:STOM.0000048399.18770.2e

[36] Yu.M. Lakhtin, et al., "Mechanical properties of nitrided niobium alloys", Metallurgist. and term. processing met., no. 10, pp. 13-17, 1973. https://doi.org/10.1007/BF00656061

[37] J. Guille and L. Matini, "Microindentation characterization of silicide coatings on niobium and titanium", J. Maters. Sci. Lett., no. 9, pp. 952-954, 1988. https://doi.org/10.1007/BF00720739

[38] Strength calculation and testing. Methods of accelerated test for thermocyclical creep -DSTU 2637-94, State Standard of Ukraine, Kiev, 1994.

[39] Thermo-mechanical fatigue of aero-engine turbine blades, Metallurgia, no. 5, 1994.

[40] V.P. Babak, et al., "Thermal barrier coatings on niobium-based alloys structural materials", Mechanics and Advanced Technologies, Vol.86, no. 2, pp. 44-50, 2019. https://doi.org/10.20535/2521-1943.2019.86.189071

[41] R. Heidenreich, U. Papenburg and R. Schäfer "Prüftechnik für Hochtemperatur - Konstruktionswerkstoff”, Mat.-wis. U. Werstofftech., no. 25, pp. 30-38, 1994.

[42] B.A. Lyashenko, et al., "Optimization of coating technology according to the criteria of strength and wear resistance", $I P P$, no. 3.2, pp. 53-58, 2010.

[43] S.D. Kharchenko, "Methods for adjusting the wear-resistance of parts of the aviation technology for the test of detonation pokrittiv Cr-Si-B”, NAU, 2019.

[44] V.P. Babak, V.P. Shchepetov and S.D. Kharchenko, "Wear resistance of self-lubricating coatings due to the formation of carbide graphite", Mechanics and Advanced Technologies, Vol.89, no. 2, pp. 593-598, 2020.

https://doi.org/10.20535/2521-1943.2020.89.211170 
[45] V.P. Babak, et al., "Suprun Intrastructural regeneration of coatings during friction", Physical and chemical mechanics of materials, no. 1, pp. 1-6, 2019. https://doi.org/10.1007/s11003-019-00248-5

[46] B.A. Lyashenko, O.V. Tsygulev and L.B. Kuznetsov, "Is it always necessary to increase the adhesive strength of protective coatings", Problems of strength, no. 5, pp. 70-74, 1987. https://doi.org/10.1007/BF01524302

[47] M.C. Ageev, et al., "Performance of protective compound coating for NCU niobium alloy evaluated by thermos-cyclic creep test method", Material protection, no. 50(2), pp. 15-19, 2017.

[48] B.A. Lyashenko, N.V. Novikov and S.A. Klimenko, Discrete modification of the surface layer of machine parts and tools. ISM, 2017.

[49] V.P. Babak, V.V. Shchepetov and S.D. Kharchenko, "Antifriction Nanocomposite Coatings that Contain Magnesium Carbide", Mechanics and Advanced Technologies, Vol. 40, no. 6, pp.593-598, 2019. https://doi.org/10.3103/S1068366619060035

[50] Y.H. Zhang et al., "Damage mechanisms of coated systems under hermomechanical fatigue", Mater Sci. and Technol, no. 9 , pp. 1031-1036, 1999. https://doi.org/10.1179/026708399101506896

[51] Method of applying non-critical coatings on non-metallic materials (in Ukraine), UA, Pat. 26555, bul., №152007.

\section{Теплозащитные покрытия на ниобиевых сплавах}

\section{В. П. Бабак, Б. А. Ляшенко, В. В. Щепетов, С. Д. Харченко}

Аннотация. Рассмотрены различные составы и технологии получения теплозашитных покрытий. Анализ выявил, что при плазменно-диффузионной нанесении на поверхности ниобиевых сплава формировалось многослойное покрытие. Высокопористый плазменно-напьленный слой силицица молибдена имеет значительный разброс по толщине (h=100...350 мкм, $H_{\mu}{ }^{20}=6880$ МПа). При исследовании микроструктуры образцов с плазменно-диффузионным покрытием после испытаний обнаружено, что трещины в покрытии зарождаются в прочессе ползучести большей частью на границе раздела плазменного и диффузионного слоев покрытия. Очагом их зарождения являются отдельные несплошности в диффузионном слое в состоянии поставки. Распространение трещцин происходит как в плазменный, так и в диффузионный слои покрытия. Торможение роста трешин в плазменном слое происходит за счет округлого характера пор и повышенной пластичности этого слоя. Рост трещин вглубь образиа, как правило, тормозится боридным подслоем. Преимущество плазменно-диффузионной технологии обеспечило повышенную пластичность покрытия, наличие тонких барьерных подслоев, несплочную структуру покрытия, наличие легкоплавких соединений, способствующих залечиванию дефектов в покрытии, повыцению его коррозионной стойкости и сопротивлению термоусталостному разрушению. Сочетание этих свойств позволило обеспечить повьшение долговечности по сравнению с силицинными и боросилицидными покрытиями в условиях изотермической ползучести на воздухе $\left(1400^{\circ} \mathrm{C}, 50 \mathrm{MПа)} 1,9 \ldots 3,7\right.$ раза и в условиях термоциклической ползучести (1400↔250 ${ }^{\circ} \mathrm{C}, 50 \mathrm{MПа)} \mathrm{в} 6,8 \ldots 8,5$ раз. Определено, что применение дискретной структуры позволит увеличить толщину слоя покрытий и обеспечить повышение их рабочих свойств.

Ключевые слова: сплав, многокомпонентные покрытия, плазменно-диффузионные покрытия, жаропрочность, жаростойкосmb.

\section{Теплозахисні покриття на ніобісвих сплавах}

\section{В. П. Бабак, Б. А. Ляшенко, В. В. Щепетов, С. Д. Харченко}

Анотація. Розглянуто різноманітні склади і технологї отримання теплозахисних покриттів. Аналіз виявив, щуо при плазмодифузійному нанесенні на поверхні ніобієвого сплаву формувалось багатошарове покриття. Високопористий плазмо-напилений шар силіциду молібдену має значний розкид по товщині $\left(h=100 \ldots 350\right.$ мкм, $H_{\mu}{ }^{20}=6880$ МПа). При дослідженні мікроструктури зразків з плазмо-дифузійним покриттям після випробувань виявлено, щчо тріщини в покритті зароджуються в прочесі повзучості здебільшого на границі розділу плазмового і дифузійного шарів покриття. Осередком їх зародження є окремі несуиільності в дифузійному шарі в початковому стані. Поширення тріщин відбувається як в плазмовий, так і в дифузний шари покриття. Гальмування зростання тріщин в плазмовому шарі відбувається за рахунок округлого характеру пор і підвищеноі пластичності иього шару. Зростання тріщин вглиб зразка, як правило, гальмується боридним підщаром. Перевага плазмодифузійної технології забезпечила підвищену пластичність покриття, наявність тонких бар'єрних підщарів, несуцільну структуру покриття, наявність легкоплавких з'єднань, що сприяють заліковуванню дефектів в покритті, підвищенню його корозійної стійкості і опору термовтомлювальному руйнуванню. Поєднання иих властивостей дозволило забезпечити підвищення довговічності в порівнянні з силіцидними і боросиліцидними покриттями в умовах ізотермічної повзучості на повітрі $\left(1400^{\circ} \mathrm{C}, 50 \mathrm{MПа)} 1,9 \ldots 3,7\right.$ рази і в умовах термоциклічної повзучості $\left(1400 \leftrightarrow 250^{\circ} \mathrm{C}, 50 \mathrm{MПа)} \mathrm{в} \mathrm{6,8..8,} 5\right.$ раз. Визначено, щео застосування дискретної структури дозволить збільщити товщину шару покриттів та забеспечити підвищення їх робочих властивостей.

Ключові слова: сплав, багатокомпонентні покриття, плазмо-дифузійні покриття, жароміиність, жаростійкість. 